\title{
SISTEM KENDALI TERPADU PERALATAN LISTRIK MENGGUNAKAN RASPBERRY PI BERBASIS JARINGAN KOMPUTER TOPOLOGI STAR
}

\author{
Zuly Budiarso ${ }^{1}$, Eddy Nurraharjo ${ }^{2}$ \\ Program Studi Teknik Informatika, Fakultas Teknologi Informasi, Universitas Stikubank \\ e-mail: ${ }^{1}$ zulybudiarso@edu.unisbank.ac.id
}

\begin{abstract}
Abstrak
Perkembangan teknologi sistem dari sistem analog menjadi sistem digital merupakan salah satu hal yang menjadi awal berkembangnya sistem kendali didgital. Dengan berubahnya sistem kendali analog menjadi sistem kendali digital maka jenis perangkat yang digunakan untuk mengimplementasikan sistem kendali juga berbahjuga berubah. Mikrokontroler adalah salah perangkat yang berfungsi sebagai perangkat utama dalam sistem kendali digital.

Dengan mikrokontroler perancangan sistem kendali dapat dilakukan lebih efisien. Kemampuan mikrokontroler dalam sistem kendali dilengkapi dengan berbagai fitur penunjang, diantaranya prosessor, memory, A/D converter, analog/digital input/output dan beberapa kemampuan lain untuk mengolah data digital maupun analog.

Seiring dengan perkembangan teknologi di bidang komputer, perangkat sistem kendali juga semakin berkembang dari mikrokokontroler beralih ke komputer. Hal ini disebabkan kebutuhan perangkat yang dapat mendukung fungsi sistem kendali itu sendiri. Sistem kendali dituntut untuk dapat menyelesaikan berbagai permasalahan yang cukup rumit. Untuk dapat memenuhi kebutuhan sesuai dengan tuntutan keadaan maka personal komputer merupakan perangkat alternatif yang dapat digunakan sebagai pengganti mikrokontroler.

Raspberry Pi yang yang merpakan sebuah mini komputer Single Board Circuit merupakan pilihan yang dapat dilakukan auntuk menyelesaikan masalah sistem kendali. Secara umum spesifikasi teknis raspberry pi dapat mendukung sebuah sistem kendali dengan tingkat kesulitan tinggi. Fitur-fitur yang ada pada raspberry pi seperti memori, prosesor sudah dapat menyelesaikan masalah sistem kontrol. Perangkat I/O seperti USB, HDMI, dan kebutuhan daya yang kecil merupakan kelebihan dari raspberry. Selain itu raspberry juga dilengkapi dengan perangkat untuk komunikasis, yaitu Bluetooth dan wifi. Dengan demikian dapat dikatakan bahwa raspberry merupakan mini komputer yang dapat digunakan dalam sistem kendali.

Dengan menggunakan sebuah program, raspberry dapat digunakan untuk mengendalikan perangkat listrik seperti mematikan dan menghidupkan lampu dari jarak jauh, membuka dan menutup pintu, mengendalikan kamera dan berbagai macam peralatan listrik. Adanya bluetooth dan wifi memungkinkan raspberry dapat dioperasikan dari jarak jauh melalui jaringan internet atau jaringan komputer lokal.

Selain menggunakan perangkat nirkabel, raspbery juga dilengkapi dengan LAN Card. Sehingga untuk kemunikasi dengan raspbery dapat dilakukan melalui jaringan lokal. Dengan menggabungkan beberapa raspbery dalam sebuah jaringan lokal (LAN) terbentuklah sistem kendali berbasis jaringan komputer.
\end{abstract}

Kata Kunci : Raspberry Pi, Kendali, LAN

\section{PENDAhUluan}

Perancangan sebuah sistem digital pada umumnya terdiri 3 tahapan. Tahap pertama adalah merancang model sistem digital. Pada tahap ini ditentukan semua parameter yang berhubungan, model sistem digital, kebutuhan perangkat keras dan perangkat lunak. Tahap kedua adalah perancangan algorithma untuk menyelesaikanb masalah dalam sistem kendali. Pada tahap ini dibuat tahap demi tahap proses penyelesaian masalah sistem digital secara rinci dan perancangan program. Tahap ketiga adalah implementasi dan pengujian sistem digital. Pengujian yang dilakukan adalah dengan mencoba semua fasilitas yang tersedia dalam sistem kendali 
Perubahan Sistem kendali analog menjadi sistem kendali digital merupakan salah satu dampak perkembangan teknologi digital. Dengan berubahnya sistem kendali analog menjadi sistem kendali digital maka jenis perangkat yang digunakan juga berubah. Salah satu kelebihan sistem kendali digital adalah adanya perangkat yang dapat diprogram sedemikian rupa sehingga mudah dilakukan modifikasi untuk memperoleh hasil yang optimal.

Mikrokontroler merupakan perangkat yang mewakili suatu figur sistem kendali modern yang telah telah dikemas dalam sebuah chip / rangkaian terpadu. Dengan mikrokontroler perancangan sistem kendali dapat dilakukan lebih efisien. Kemampuan mikrokontroler dalam sistem kendali dilengkapi dengan berbagai fitur penunjang, diantaranya prosessor, memory, A/D converter, analog/digital input/output dan beberapa kemampuan lain untuk mengolah data digital maupun analog.

Seiring dengan perkembangan teknologi di bidang komputer, perangkat sistem kendali juga semakin berkembang dari mikrokokontroler beralih ke komputer. Hal ini disebabkan kebutuhan perangkat yang dapat mendukung fungsi sistem kendali itu sendiri. Sistem kendali dituntut untuk dapat menyelesaikan berbagai permasalahan yang cukup rumit. Untuk dapat memenuhi kebutuhan sesuai dengan tuntutan keadaan maka personal komputer merupakan perangkat alternatif yang dapat digunakan sebagai pengganti mikrokontroler.

Sistem kendali dituntut untuk dapat menyelsaikan masalah yang rumit. Sehingga dibutuhkan prosesor dengan kecepatan tinggi. Memori juga merupakan masalah yang harus diperhatikan. Untuk menyelesaikan masalah yag rumit tentunya dibutuhkan program dengan kapasitas memori yang besar.

Raspberry Pi yang yang merpakan sebuah mini komputer Single Board Circuit merupakan pilihan yang dapat dilakukan auntuk menyelesaikan masalah sistem kendali . Secara umum spesifikasi teknis raspberry pi dapat mendukung sebuah sistem kendali dengan tingkat kesulitan tinggi. Fitur-fitur yang ada pada raspberry pi seperti memori, prosesor sudah dapat menyelesaikan masalah sistem kontrol. Perangkat I/O seperti USB, HDMI, dan kebutuhan daya yang kecil merupakan kelebihan dari raspberry. Selain itu raspberry juga dilengkapi dengan perangkat untuk komunikasis, yaitu Bluetooth dan wifi. Dengan demikian dapat dikatakan bahwa raspberry merupakan mini komputer yang dapat digunakan dalam sistem kendali.

\section{TINJAUAN PUSTAKA}

Raspberry Pi merupakan sebuah perangkat yang dapat berfungsi seperti sebuah komputer personal. Perangkat ini berukuran fisik sangat kecil, sehingga sangat praktis jika digunakan untuk berbagi keperluan yang tidak terlalu membutuhkan memori yang besar untuk mengolah data. Dengan fitur yang ada raspberry dapat digunakan sebagai perangkat pengganti mikrokontroler. Dengan dilengkapi modul I/O yang dapat digunakan sebagai masukan maupun keluaran sinyal digital maupun sinyal analog maka raspberry dapat digunakan layaknya sebuah mikrokontroler yang dapat digunakan untuk sistem kendali.

Sebuah perangkat dapat digunakan dalam sistem kendali jika mempunyai kemampuan dapat menerima masukan berupa sinyal analog dan sinyal digital. Raspberry dilengkapi dengan $A / D$ converter dan D/A converter sehingga mampu mengolah sinyal digital dan mengubah menjadi sinyal analog atau sebaliknya.

Masukan dari perangkat lain pada raspberry dilakukan dengan menghubungkan perangkat modul I/O pada raspberry. Pada raspberry pi 3 terdapat 30 buah pin yang berfungsi sebagai masukan atau keluaran. Sedangkan pin yang lain berupa sember tegangan kutub positip dan negatip.

Dengan menggunakan sebuah program, raspberry dapat digunakan untuk mengendalikan perangkat listrik seperti mematikan dan menghidupkan lampu dari jarak jauh, membuka dan menutup pintu, mengendalikan kamera dan berbagai macam peralatan listrik. Adanya bluetooth dan wifi memungkinkan raspberry dapat dioperasikan dari jarak jauh melalui jaringan internet atau jaringan komputer lokal.Selain menggunakan perangkat nirkabel, raspbery juga dilengkapi dengan LAN Card. Sehingga untuk kemunikasi dengan raspbery dapat dilakukan melalui jaringan lokal. 
Menurut Eddy Nuraharjo[2] penggunaan dasar sistem terpadu aplikasi dalam sistem robotika dengan menggunakan IC mikrokontroler AT89S52 yang memiliki kapasitas 8 kilobyte memori mampu memberikan beberapa tempat memori untuk program-program yang berisi 'kecerdasan dasar buatan', bisa menggunakan bahasa $\mathrm{C}$ atau bahasa assembler, bagi 'robot' untuk menentukan pergerakan arah dan 'manuver cerdas'sebagai bentuk eksekusi terhadap kejadian yang ditentukan pada kondisi jalur yang ada dengan bantuan rangkaian sensor infra red. Sebuah simulasi robot dalam penelitian ini menggunakan mobil konvesional yang diharapkan dapat memiliki 'kecerdasan buatan' dengan memantau kondisi jalur yang akan dilaluinya, dan mampu melakukan 'manuver cerdas' sesuai dengan keadaan jalur tersebut. Mobil robot dengan Self Running adalah pengendalian gerakan dari robot yang berdasarkan program kemudi yang diberikan sehingga seolaholah robot tersebut bergerak sendiri. Jenis ini tidak tergantung dari kemudi seorang operator dan juga biasanya ditempatkan beberapa jenis sensor untuk mendeteksi situasi sekelilingnya (untuk mengenali medan jelajahnya). Sensor tersebut akan memberikan informasi kepada sistem robot, kemudian oleh perangkat prosessor atau controll informasi tersebut diolah, yang natinya dijadikan sebagai acuan dalam melakukan pergerakan selanjutnya. Self Runnning dapat dikategorikan lagi menjadi dua jika dilihat dari tingkat kecerdasan robot tersebut, yakni robot dengan kecerdasan buatan dan tanpa kecerdasan buatan. Robot dengan kecerdasan buatan memiliki maksud bahwa robot tersebut berkemampuan secara sendiri untuk merespon atau bereaksi didalam kondisi yang tidak ditentukan sebelumnya. Selanjutnya robot dengan tanpa kecerdasan buatan secara keseluruhan tergantung kepada intstruksi yang diberikan.

Perancangan sebuah sistem kendali dengan menggunakan mikrokontroler terdiri 3 tahapan.[8] Tahap pertama adalah merancang model sistem kendali. Pada tahap ini ditentukan semua parameter yang berhubungan, model sistem kendali, kebutuhan perangkat keras dan perangkat lunak. Tahap kedua adalah perancangan algorithma untuk menyelesaikanb masalah dalam sistem kendali. Pada tahap ini dibuat tahap demi tahap proses penyelesaian masalah sistem kendali secara rinci dan perancangan program. Tahap ketiga adalah implementasi dan pengujian sistem kendali. Pengujian yang dilakukan adalah dengan mencoba semua fasilitas yang tersedia dalam sistem kendali.

Raspbery Pi juga dapat digunakan untuk pemantuan rumah. Menurut Sanjana Prasad [ 6 ] dalam makalahnya yang berjudul Smart Surveillance Monitoring System Using Raspberry PI and PIR Sensor menyebutkan bahwa raspberry pi dapat digunakan untuk memantau keadaan rumah melalui telepon genggam. Sebuah sensor PIR digunakan untuk mendeteksi gerakan di sekitar sensor. Cara kerja sensor PIR adalah jika sensor menangkap sebuah gerakan di sekitarnya, maka akan merespon gerakan tersebut dan mengirimkan sinyal ke raspberry pi. Selanjutnya raspberry pi akan mengirimkan pesan ke perangkat telepon genggam. Dengan menggunakan aplikasi yang dibuat khusus untuk masalah ini maka setiap user dapat memantau kondisi rumah setiap saat dari mana saja.

Sheikh Ferdoush [ 7 ] dalam papernya yang berjudul Wireless Sensor Network System Design using Raspberry Pi and Arduino for Environmental Monitoring Applications mengembangkan raspberry untuk teknologi jaringan nirkabel. System yang dirancang dapat diterapkan pada berbagai bidang, menggunakan perangkat keras open source, yaitu raspberry dan arduino dengan biaya rendah. Sensor yang digunakan dapat diatur sebsuai dengan keadaan lingkungan. Jaringan sensor merupakan sebuah sistem mikrokontroler yang tertanam di dalam sebauah perangkat dengan daya rendah dan port I/O yang berfungsi menerima masukan dari luar perangkat seperti sensor maupun mengirimkan sinyal keluar perangkat seperti telepon genggam atau perangkat yang lain.

\section{METODE PENELITIAN}

Metode prototipe yang akan digunakan dalam penelitian ini terdiri dari langkah-langkah sebagai berikut ;

1. Studi Literatur

Untuk memperoleh dasar teori berkaitan dengan pemrograman sistem kendali digital, mikrokontroler, pemrograman raspberry baik berasal dari jurnal, buku maupun informasi baku lainnya yang bersumber dari situs-situs di internet. Untuk mendukung pemahaman tentang raspberry pi dan jaringan komputer digunakan modul jaringan komputer dan datasheet raspberry pi 
2. Pemrograman Aplikasi

Pemrograman aplikasi ini dimaksudkan untuk menguji sebuah teknik serta mengeksplorasi teknik interfacing dan mengimplementasikannya metode tersebut dalam sebuah aplikasi berbasis raspberry, dengan menggunakan bahasa pemrograman phyton, hingga terimplementasikannya sistem kendali melalui jaringan komputer.

3. Metode perakitan atau pengujian

Rangkaian hasil perancangan dirakit dalam sebuah papan percobaan dan diberikan tes atau uji kelayakannya serta mendeteksi kekurangan alat yang dibuat untuk diperbaiki dan disesuaikan dengan hasil yang sesuai dengan rancangan yang diharapkan. Uji coba yang dilakukan adalah dengan membandingkan hasil proses sistem kendali secara manual dengan hasil yang diperoleh dari perintah melalui raspberry yang dikendalikan dari jarak jauh melaui jaringan komputer (LAN)

\section{HASIL DAN PEMBAHASAN}

\subsection{Rancangan Sistem Kendali}

Sistem kendali dengan menggunakan raspberry pi adalah sebuah sistem kendali yang menggunakan raspberry sebagi perangkat utama. Raspberry dilengkapi dengan fitur-fitur yang dpat digunakan sebagai sistem kendali. Salah satu syarat sistem kendali adalah adanya modul I/O yang berfungsi sebagai media komunikasi antar muka suatu peralatan dengan peralatan lain. Modul I/O berisi $\mathrm{A} / \mathrm{D}$ converter dan $\mathrm{D} / \mathrm{A}$ converter yang berfungsi sebagai pengubah sinyal analog menajadi sinyal digital. Sinyal yang berasal dari piranti yang menghasilkan besaran analog seperti tegangan dan arus tidak dapat diolah oleh raspberry yang berfungsi sebagai mikrokontroler karena hanya sinyal digital yang dapat diproses oleh raspberry. Untuk mengubah sinyal analog menjadi sinyal digital atau sebaliknya raspberry dilengkapi dengan A/D converter.

Pada umumnya sinyal yang berasal dari perangkat di luar raspberry adalah perangfkat yang menghasilkan sinyal analog. Sensor adalah sebuah perangkat yang berfungsi mengubah besaranbesaran analog menjadi besaran besaran listrik. Sinyal yang dihasilkan oleh sensor hanya berupa pulsa listrik dengan frekuensi tertentu. Sinyal dari sensor sudah diubah menjadi sinyal analog belum bisa diolah oleh raspberry. Dengan A/D converter yang ada di dalam raspberry, sinyal tersebut dapat dijadikan sebagai masukan untuk mengubah nilai-nilai analaog menjadi besaran digital. Dengan diubahnya besaran analog menjadi besaran digital maka semua proses digital dapat dilakukan pada sinyal tersebut diantaranya menampilkan hasil di LCD, mentriger indikator, masukan untuk sistem sinyal dan lain-lain. Sistem kendali dengan raspberry dapat mengendalikan perangkat lain di luar raspberry menggunakan sebuah perintah yang ditulis dengan bahasa pemrgoraman. Blok Diagram Sistem Kendali dapat dilihat pada gambar 1.

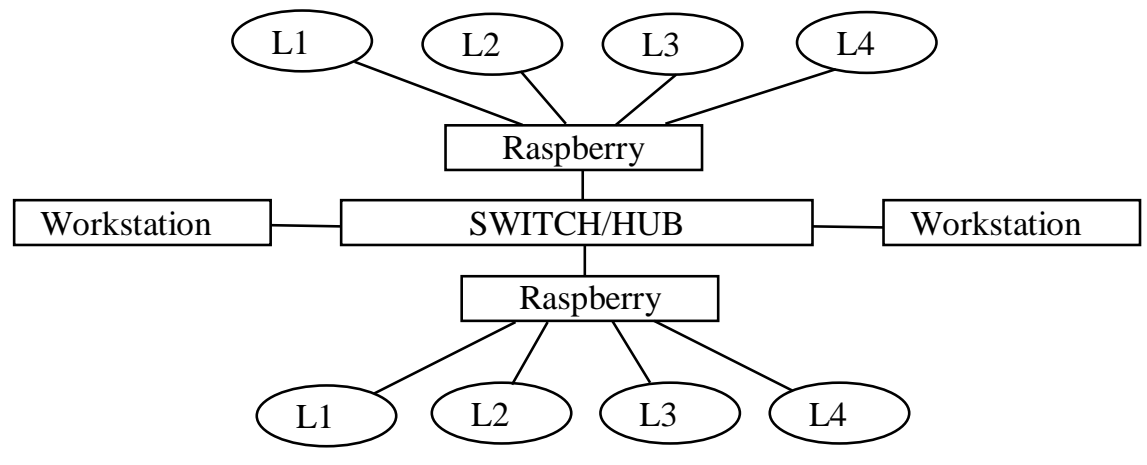

Gambar 1. Blok Diagram aamSistem Kendali

Peralatan yang digunakan dalam sistem kendali adalah sebagai berikut :

1. Switch/Hub : berfungsi sebagai penghubung antara workstation dengan raspberry

2. Workstation : Terminal Pengendali berupa sebuah komputer

3. L1,L2,L3,L4 : Peralatan listrik yang akan dikendalikan 


\subsection{Rancangan Perangkat Keras sistem kendali}

Sistem kendali dengan raspberry yang paling sederhana terdiri dari sebuah raspberry yang diprogram sedemikian rupa sehingga dapat mengendalikan beberapa perlatan listrik. Sebuah raspberry dapat digunakan untuk mengendalikan paling banyak 25 peralatan listrik, karena sebuah raspberry terdapat 25 pin I/O yang dapat digunakan untuk masukan ataupun keluaran. Blok diagram sistem kendali sebuah raspberry dapat dilihat pada gambar 2 .

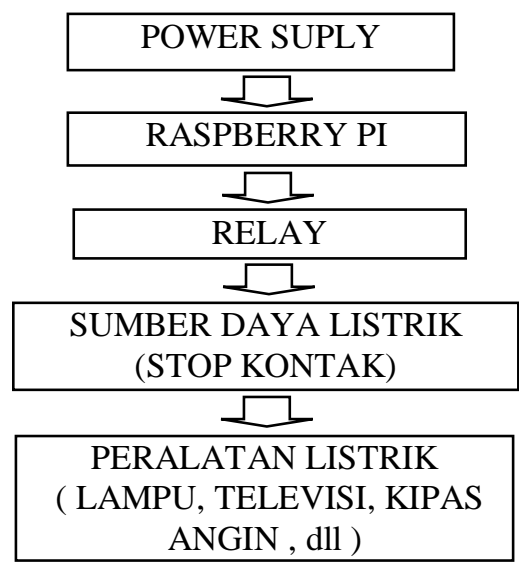

Keterangan :

Gambar 2. Blok Diagram Sistem Kendali Raspberry Pi

1. Power Suply : Berfungsi sebagai catu daya bagi raspberry. Keluaran dari power suply adalah sebuah arus DC dengan tegangan 5 volt dan maksimum arus 2 Ampere.

2. Raspberry Pi : Perangkat Utama sistem kendali

3. Relay : Sebuah rangkaian elektronik yang berfungsi sebagai switch. Realay akan bekerja setelah mendapat sinyal triger dari raspberry.

4. Sumber Daya listrik: Berfungsi sebgai sumber daya bagi perlatan elektronik yang akan dikendalikan oleh raspberry.

5. Peralatan listrik : Beberapa peralatan listrik yang dijadikan sebagai target dalam sistem kendali.

Jumlah raspberry dan komputer yang digunakan dalam sistem kendali dengan raspberry disesuaikan dengan kebutuhan.

\subsection{Rancangan Perangkat Lunak sistem kendali}

Sistem kendali dengan menggunakan raspberry dapat dilihat pada diagram alir pada gambar 3 . Program utama yang dimasukkan pada raspberry adalah sebuah perintah untuk mengaktifkan dan menonaktifkan GPIO, yaitu beberapa port pada raspberry yang berfungsi sebagai masukan dan keluaran.

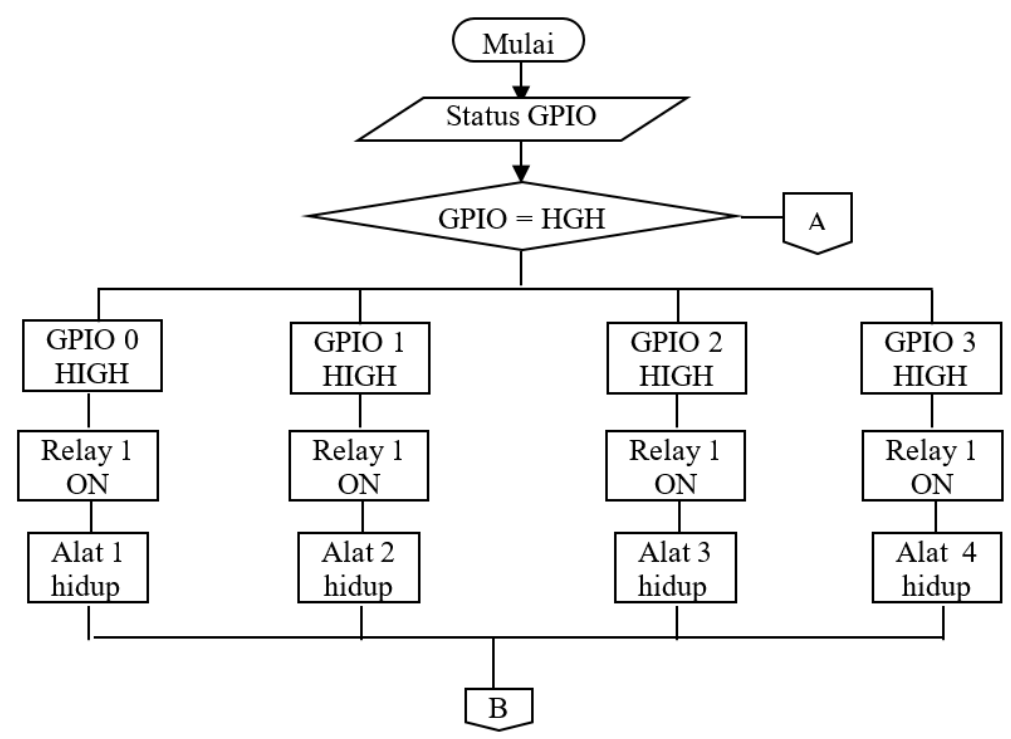




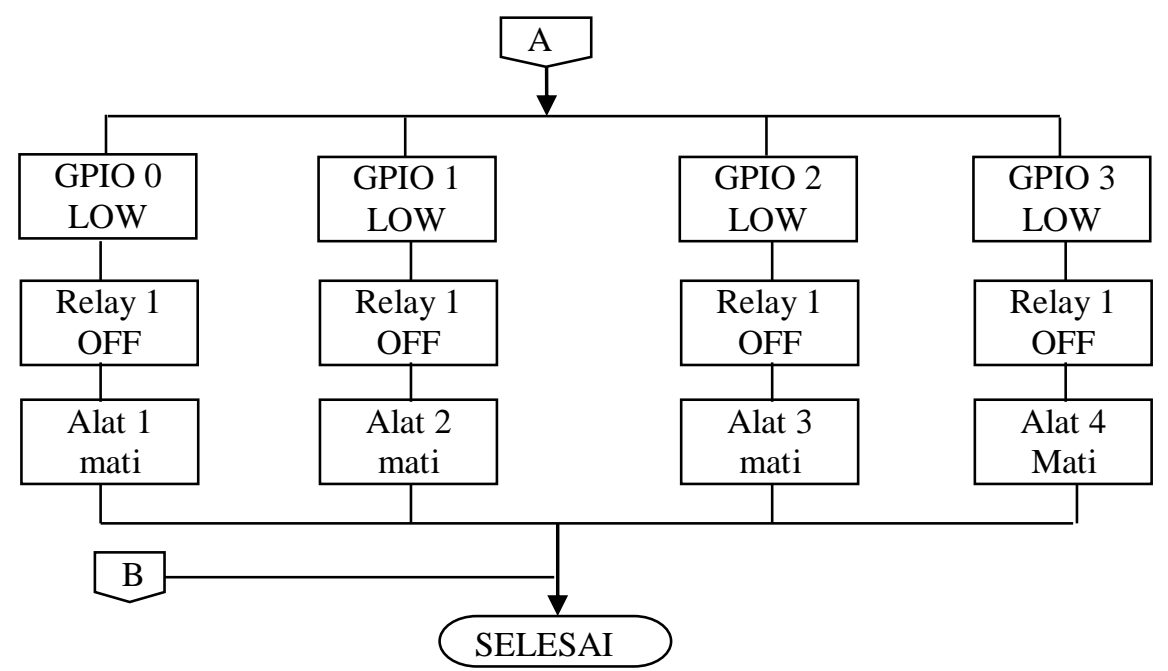

Gambar 3. Flowchart Program Sistem Kendali Raspberry Pi

Langkah pertama proses dalam program adalah inisial GPIO. Inisial GPIO adalah sebuah program yang berfungsi memberikan nilai awal pada GPIO. Nilai yang diberikan pada GPIO adalah berupa kondisi HIGH atau LOW. Kondisi HIGH menunjukkan GPIO bernilai logika "1", dan terdapat tegangan sebesar \pm 5 volt. Nilai inilah yang digunakan sebagai triger pada relay. Relay adalah sebuah alat yang berfungsi sebagai electric switch. Sebuah lilitan pada suatu batang logam yang dihubungkan suatu sumber tegangan akan menghasilkan GGL induksi atau magnet pada logam. Magnet yang dihasilkan akan menarik sebuah pengungkit yang dihubungkan dengan sumber tegangan. Terdapat dua jenis keadaan relay, yaitu Normally Close dan Normally Open. Normally Close $(N C)$ yaitu kondisi awal sebelum diaktifkan akan selalu berada di posisi CLOSE (tertutup). Sedangkan Normally Open (NO) yaitu kondisi awal sebelum diaktifkan akan selalu berada di posisi OPEN (terbuka). Sebuah relay dapat digunakan untuk mengaktifkan beberapa jenis perlatan elektronik, tergantung jumlah kaki yang terdapat pada relay. Untuk mengendalikan satu jenis peralatan diperlukan 4 buah kaki relay. Dua kaki berasal dari kedua ujung lilitan yang dibungkan dengan sumber tegangan DC. Sedangkan dua kaki yang lain berfungsi sebagai skalar.

Masukan dalam sistem kendali adalah berupa perintah yang berisi memberikan nilai yang berupa "HIGH" atau "LOW" ke modul GPIO. Dalam penelitian ini menggunakan 4 buah port GPIO, yaitu GPIO0, GPIO1, GPIO3 dan GPIO4. Setiap GPIO terhubung dengan sebuah relay. Kondisi GPIO inilah yang akan menentukan kondisi relay apakah "OFF" atau "ON" Jika nilai masukan adalah HIGH maka kondisi relay adalan ON. Setiap relay terhubung dengan sumber tegangan. Sumber tegangan digunakan untuk menghidupkan peralatan listrik atau elektronik yang mebutuhkan tenaga listrik. Dalam penelitian ini menggunakan 4 buah lampu. Masing-masing lampu dapat dikendalikan tersendiri. Sehingga setiap lampu bisa diatur menyala atau padam. Nilai awal GPIO diatur pada kondisi LOW, sehingga relay pada keadaan NC, dan lampu padam.

\subsection{Kendalai Modul Relay}

Modul relay adalah sebuah rangkaian elektronik yang berfungsi sebagai penghubung antara mikrokontroler dengan perangkat yang akan dikendalikan. Sebuah transistor berfungsi menerima masukan yang berupa arus DC dengan tegangan \pm 5 volt yang berasal dari port GPIO raspberry. Arus tersebut akan digunakan sebagai sinyal triger untuk meyulut transistor mengalirkan arus listrik dari kaki basis ke kaki kolector. Jika kaki kolektor mendapat suply arus maka akan menimbulkan tegangan pada kaki kaki kolektor dengan kaki emitor yang terhubung dengan ground ( kutub negatif). Tegangan inilah yang mengubah relay dari keadaan NC menjadi NO atau sebaliknya. Rangkaian lengkap kendali relay dapat dilihat pada gambar 4. 


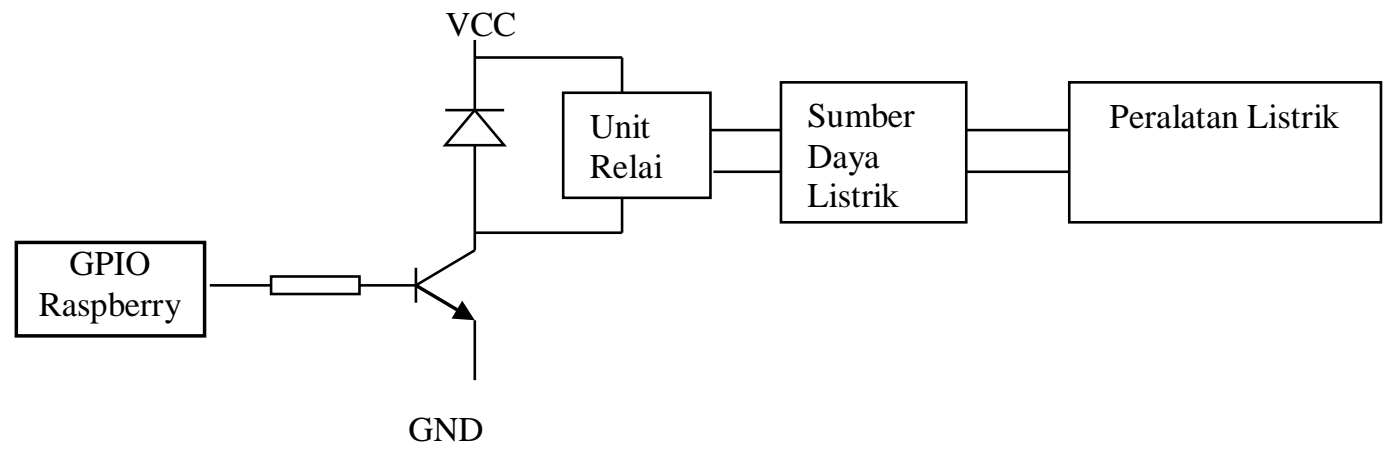

Gambar 4. Rangkaian Kendali Relay

\subsection{Diagram Sistem Kendali Raspberry}

Dalam uji coba tipe raspberry yang digunakan adalah raspberry pi 3 type B. Rancangan sistem kendali menggunakan raspberry pi 3 type B adalah seperti pada ganbar 5.6. Pin GPIO yang digunakan adalah GPIO0, GPIO1, GPIO2 dan GPIO3.

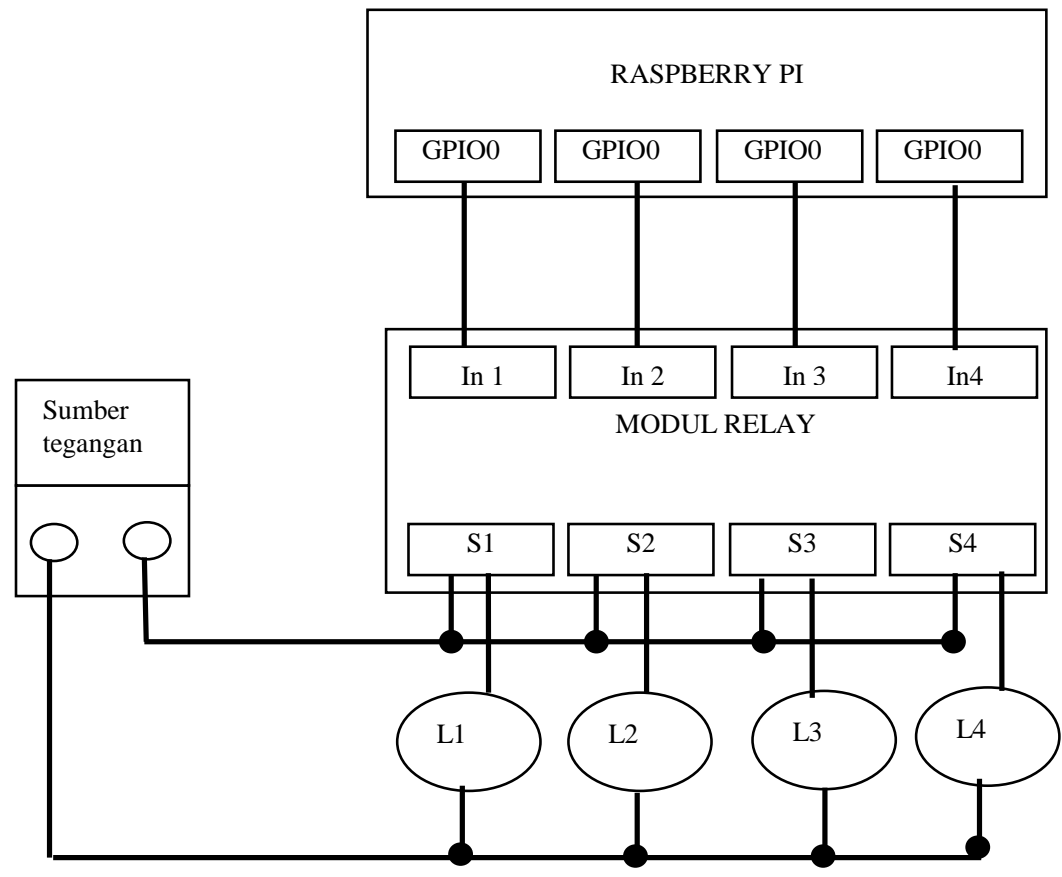

Gambar 5. Skematik Diagram Sistem Kendali

Keterangan :

1. GPIO0, GPIO1,GPIO2, GPIO4 adalah port GPIO raspberry pi

2. In1, In2, In3, In 3 adalah line input modul relay

3. S1, S2, S3, S4 adalah saklar relay

4. L1, L2, L3, L4 adalah Lampu

\subsection{Hasil Pengujian}

Selain modul raspberry dan modul relay sebagai perangkat utama, sistem kendali menggunakan raspberry juga membutuhkan beberapa alat pendukung, yaitu sebuah kotak plastik berfungsi untuk meletakkan komponen-komponen, lampu indikator dan kabel jumper. Sebelum diletakkan di tempat yang semestinya, semua komponen dan alat harus diuji coba dulu kinerjanya. Sinyal yang dihasilkan oleh raspberry adalah berupa sinyal digital, sehingga uji coba dilakukan dengan menggunakan lampu LED yang diletakkan di projectboard sebagai indikator. Dalam uji coba ini terdapat 9 buah LED sebagai indikator. Setiap indikator menunjukkan kinerja dari GPIO, modul relay dan lampu. 
Relay juga dapat digunakan sebagai saklar untuk menghidupkan atau memadamkan sebuah lampu. Keadaan ON dan OFF lampu tergantung kondisi GPIO. Untuk memberikan nilai pada GPIO dilakukan dengan menjalankan program.

Program yang digunakan untuk sistem kendali raspberry adalah bahasa python. Bahasa pemrograman python termasuk bahasa pemrograman tingkat tinggi. Alasan digunakan bahasa python karena tersedianya perintah untuk mengakses perangkat eksternal dengan mudah. Raspberry merupakan perangkat yang dapat digunakan untuk mengimplementasikan program bahasa python

Langkah pertama dalam pengujian sistem adalah merangkai peralatan seperti gambar 6 .

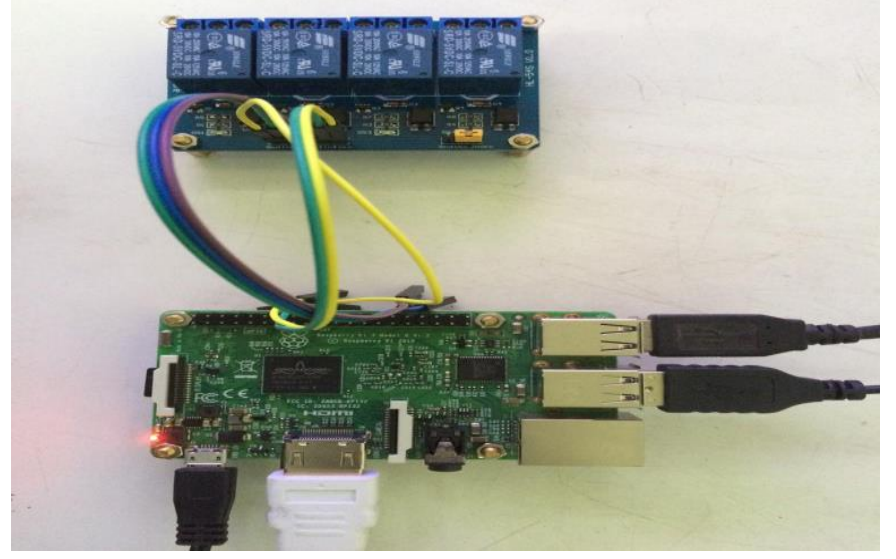

Gambar 6. Rangkaian Pengujian

Relay dihubungkan dengan sumber tegangan AC 220 Volt. Dalam pengujian digunakan 4 buah relay yang dihubungkan dengan 4 buah stop kontak ( sumber tegangan ). Untuk menjalankan program sistem kendali dilakukan dari terminal dengan perintah sebagai berikut :

1. Untuk menghidupkan Alat1 : pi@raspy: \$ sudo python hidup1.py

2. Untuk menghidupkan Alat2 : pi@ raspy: \$ sudo python hidup2.py

3. Untuk menghidupkan Alat 3 : pi@ raspy: \$ sudo python hidup3.py

4. Untuk menghidupkan Alat4 : pi@ raspy: \$ sudo python hidup4.py

5. Untuk mematikan Alat1 : pi@ raspy: \$ sudo python mati1.py

6. Untuk mematikan Alat 2 : pi@ raspy: \$ sudo python mati2.py

7. Untuk mematikan Alat 3 : pi@ raspy: \$ sudo python mati3.py

8. Untuk mematikan Alat4 : pi@ raspy: \$ sudo python mati4.py

Dari hasil percobaan diperoleh hasil bahwa setiap perintah dari terminal dapat di eksekusi dengan baik. Hal ini dapat dilihat dari relay yang dapat berfungsi sebagai switch yang menghidupkan dan mematikan alat listrik yang terhubung dengan sumber tegangan. Dari hasil pengujian diperoleh hasil sebagai berikut :

1. Untuk menyalakan dan memadamkan setiap lampu dilakukan dengan perintah sendiri.

2. Kondisi awal dari program adalah lampu dalam keadaan tidak menyala/padam, karena relay dalam keadaan NO ( Normaly OFF).

3. Semua lampu dapat dinyalakan dan dipadamkan dengan sistem kendali melalui program sesuai dengan yang diprogramkan.

4. Indikator hasil program juga dapat dilihat pada led yang ada di modul relay.

Hasil pengujian tegangan pada setiap GPIO dapat dilihat pada tabel 1.

Tabel 1. Hasil pengukuran tegangan

\begin{tabular}{|c|c|c|c|}
\hline No & GPIO & Tegangan ( Volt ) & Kondisi Lampu \\
\hline 1 & 0 & 1,57 & Padam \\
\hline 2 & 1 & 1,54 & Padam \\
\hline 3 & 2 & 1,54 & Padam \\
\hline 4 & 3 & 1,55 & Padam \\
\hline 5 & 0 & 4,83 & Menyala \\
\hline
\end{tabular}




\begin{tabular}{|l|l|l|l|}
\hline 6 & 1 & 4,77 & Menyala \\
\hline 7 & 2 & 4,75 & Menyala \\
\hline & 3 & 4,79 & Menyala \\
\hline
\end{tabular}

Dari hasil pengukuran tegangan terlihat bahwa rata-rata tegangan pada saat lampu padam adalah 1,55 volt. Hal ini menunjukkan bahwa kondisi GPIO pada saat $L O W$ adalah $\pm 1,55$ volt. Dengan tegangan 1,55 volt tidak dapat menyulut modul relaya untuk mentriger transistor agar relay berubah dari keadaan NO ke NC. Sehingga lampu tidak dapat menyala.

Keadan sebaliknya adalah pada saat lampu menyala. Tegangan yang terukur adalah $\pm 4,75$ volt. Pada keadaan tersebut GPIO dalam keadaan $H I G H$, dan lampu menyala. Dengan tegangan $\pm 4,75$ volt rangkaian relay sudah dapat bekerja dengan baik. Hasilnya adalah lampu dapat menyala dengan sesuai dengan perintah yang diberikan oleh program sistem kendali.

\section{KESIMPULAN}

Dari hasil implementasi dan pengujian sistem kendali dengan raspberry dapat disimpulkan sebagai berikut :

1. Raspberry Pi 3 type B dapat digunakan sebagai sistem kendali untuk menyalakan dan mematikan lampu melalui pin GPIO.

2. Tegangan yang dapat digunakan untuk membuat kondisi HIGH pada GPIO adalah 4,75, sedangkann untuk kondisi LOW adalah $\pm 1,55$ volt.

3. Modul Relay dapat digunakan sebagai saklar otomatis yang dapat diprogram dengan menggunakan Raspberry Pi type B

\section{SARAN}

Hasil yang diperoleh dalam penelitian masih diperlukan beberapa perbaikan untuk mengoptimalkan kinerja sistem kendali dengan raspberry pi 3, diantaranya adalh sebagai berikut :

1. Untuk menjalankan program harus melalui terminal sehingga menyulitkan operator jika tidak terbiasa dengan command line.

2. Dibuat programa dengan user interface yang mudah dioperasikan oleh operator.

3. Program menyalakan lampu dan memadamkan lampu masih terpisah, sehingga diperlukan program yang terintegrasi antara program untuk menyalakan dan program untuk mematikan lampu.

\section{DAFTAR PUSTAKA}

[1] Eddy Nuraharjo, 2015, "Sistem Kendali Mobil Robot dengan Menggunakan Mikrokontroler ATMEGA 89S52", Dinamika Teknik Vol 1, No. 2, tahun 2015,

[2] Graham C. Goodwin, Stefan F. Graebe, Mario E. Salgado, 2016, CONTROL SYSTEM DESIGN, Departamento de Electr'onica Universidad T'ecnica Federico Santa Mar'I Valpara'1so, CHILE

[3] P BHASKAR RAO, 2015, RASPBERRY PI HOME AUTOMATION WITH WIRELESS SENSORS USING SMART PHONE, Engineering, Department of Computer Science \& Engineering, P.E.S. College of Engineering, Mandya. S.K. UMA (Co-Author) Associate Professor, Department of Computer Science \& Engineering,

[4] Sheikh Ferdoush, Xinrong Li, 2016, Wireless Sensor Network System Design using Raspberry Pi and Arduino for Environmental Monitoring Applications, The 9th International Conference on Future Networks an Communications (FNC-2014), Department of Electrical Engineering, University of North Texas, Denton, Texas 76203, USA

[5] Sanjana Prasad, P.Mahalakshmi, A.John Clement Sunder, R.Swathi, 2014, Smart Surveillance Monitoring System Usin Raspberry PI and PIR Sensor, (IJCSIT) International Journal of Computer Science and Information Technologies, Vol. 5 (6) , 2014, 7107-7109

[6] Zuly Budiarso, 2016, "Analisa I/O Interfacing Technique and Programming Sistem Kendali Terpadu Berbasis Arduino UNO R3.”, Dinamika Informatika, Vol 6, Nomor 2 Tahun 2016

[7] Zuly Budiarso, 2015, "Rancang Bangun Sistem Kendali Digital Electrical Stimulator Berbasis Arduino UNO R3, Dinamika Informatika, Vol, Nomor 1 Tahun 2017

[8] https://www.raspberrypi.org/documentation/

[9] https://docs.python.org/3/tutorial/modules.html 